\title{
B Cell IgD Deletion Prevents Alveolar Bone Loss Following Murine Oral Infection
}

\author{
Pamela J. Baker, ${ }^{1}$ Nicole Ryan Boutaugh, ${ }^{1}$ Michaela Tiffany, ${ }^{1}$ and Derry C. Roopenian ${ }^{2}$ \\ ${ }^{1}$ Biology Department, Bates College, Lewiston, ME 04240, USA \\ ${ }^{2}$ Immunology/Inflammation/Hematology Section, The Jackson Laboratory, Bar Harbor, ME 04609, USA
}

Correspondence should be addressed to Pamela J. Baker, pbaker@bates.edu

Received 13 June 2009; Revised 25 July 2009; Accepted 10 August 2009

Recommended by Robert Burne

Periodontal disease is one of the most common infectious diseases of humans. Immune responses to infection trigger loss of alveolar bone from the jaw and eventual tooth loss. We investigated the contribution of B cell IgD to alveolar bone loss by comparing the response of $\mathrm{B}$ cell normal BALB/cJ mice and $\mathrm{IgD}$ deficient BALB/c-Igh-5 $5^{-/-J}$ mice to oral infection with Porphyromonas gingivalis, a gram-negative periodontopathic bacterium from humans. P. gingivalis-infected normal mice lost bone. Specific antibody to $P$. gingivalis was lower and oral colonization was higher in IgD deficient mice; yet bone loss was completely absent. Infection increased the proportion of $\mathrm{CD} 69^{+}$activated B cells and $\mathrm{CD} 4^{+} \mathrm{T}$ cells in immune normal mice compared to IgD deficient mice. These data suggest that IgD is an important mediator of alveolar bone resorption, possibly through antigen-specific coactivation of B cells and $\mathrm{CD} 4^{+} \mathrm{T}$ cells.

Copyright (C) 2009 Pamela J. Baker et al. This is an open access article distributed under the Creative Commons Attribution License, which permits unrestricted use, distribution, and reproduction in any medium, provided the original work is properly cited.

\section{Introduction}

Periodontal diseases are infectious diseases of humans and other mammals that result in damage to the soft tissue and periodontal ligaments of the gingiva, resorption of alveolar bone from the jaw, and, ultimately, loss of teeth. It is becoming increasingly apparent that there is extensive interaction and cross-talk between the immune system and bone remodeling. This new concept has wideranging implications for how we think about the causes and regulation of bone resorption and has engendered a new field called osteoimmunology $[1,2]$. Bone is constantly remodeling, with osteoblasts building bone and osteoclasts breaking it down. In a state of health, these two processes are in balance and the density of bone remains stable. This balance is disrupted in various diseases, including the osteoclastic resorptive disease, chronic periodontitis. In this periodontal disease the progressive loss of alveolar bone is largely activated by immune responses to a small subset of the more than 600 species of bacteria that colonize the oral cavity [1]. In a murine model that we have developed previously, we have shown that alveolar bone loss from the jaw can be triggered by oral infection with one of these 600 oral bacterial species, Porphyromonas gingivalis, a periodontopathic gramnegative anaerobe from humans $[3,4]$. We, and others, have shown that in response to oral infection B lymphocytes and $\mathrm{CD}^{+} \mathrm{T}$ lymphocytes of the immune system trigger bone resorption $[1,3-5]$.

Despite the prevalence of periodontal disease, the pathways to bone loss are not fully understood. In the most well-characterized pathways, infection upregulates expression of ligand for receptor activator of NF- $\kappa \mathrm{B}$ (RANK-L) on specific antigen-activated $\mathrm{B}$ and $\mathrm{CD} 4^{+} \mathrm{T}$ lymphocytes. These immune cells are then able to bind to RANK on preosteoclasts, triggering bone resorption [4-7]. We wished to explore whether there are other immune cell surface molecules that can induce bone loss. In this study we have used mice deficient in their B lymphocyte expression of IgD, a $B$ cell surface immunoglobulin known to be involved in $B$ cell/T cell cognate activation, but not known to be involved in bone remodeling.

In immune normal mice and humans, expression of membrane bound $\operatorname{IgD}$ along with $\operatorname{IgM}$ indicates that a $\mathrm{B}$ cell has undergone affinity maturation and can begin to 
react with specific antigen and secrete soluble antibody to that antigen. Igh- $5^{-/-}$mice have a targeted mutation that deletes expression of heavy chain-5 (Igh-5), the delta-like heavy chain of IgD immunoglobulin [8]. Mice deficient in IgD display a delay in $\mathrm{B}$ cell affinity maturation [8]. In addition, $\mathrm{B}$ cell membrane $\mathrm{IgD}$ is a ligand for $\mathrm{IgD}$ receptors that are expressed on activated $\mathrm{CD} 4^{+} \mathrm{T}$ cells [9]. Binding of IgD to IgD receptors facilitates $\mathrm{B}$ cell antigen presentation to $\mathrm{CD} 4^{+} \mathrm{T}$ cells by stabilizing $\mathrm{T}$ cell receptor binding to the antigen/MHC complex. This cognate interaction increases both antibody responses by the B cells and antigen-specific clonal expansion of the T cells [9]. We therefore designed experiments using Igh- $5^{-/-}$mice to test the hypothesis that $\mathrm{IgD}$ can contribute to alveolar bone loss in response to $P$. gingivalis infection.

\section{Materials and Methods}

2.1. Animals. Specific pathogen-free BALB/c-Igh- $5^{-/-J}$ mice that are $\mathrm{IgD}$ deficient due to a specific deletion of the Igh gene $[8]$ and the genetically matched immune normal strain $\mathrm{BALB} / \mathrm{cJ}$ were received from The Jackson Laboratory (Bar Harbor, ME, USA). Mice were kept in the animal colony at Bates College under conditions described previously [10]. The experimental protocol was reviewed and approved by the Institutional Animal Care and Use Committee, Bates College.

2.2. Bacteria. P. gingivalis ATCC 53977 (A7A1-28) was maintained frozen in defibrinated sheep's blood at $-80^{\circ} \mathrm{C}$. For experiments, bacteria were anaerobically grown under $5 \% \mathrm{CO}_{2}, 10 \% \mathrm{H}_{2}$ and $85 \% \mathrm{~N}_{2}$ at $37^{\circ} \mathrm{C}$ for $4-7$ days on supplemented blood agar containing trypticase soy agar base with $0.1 \%$ yeast extract, hemin $(5.0 \mu \mathrm{g} / \mathrm{mL})$, menadione $(0.5 \mu \mathrm{g} / \mathrm{mL})$, and $5 \%$ defibrinated sheep's blood. Bacteria were removed from the plates, gently suspended in phosphate-buffered saline (PBS), and diluted to $10^{10}$ colony forming units (CFU) per $\mathrm{mL}$ on the basis of optical density. Pilot experiments in which serial dilutions of $P$. gingivalis were plated for colony counts had shown that a 1:100 dilution of $10^{10} \mathrm{CFU}$ per $\mathrm{mL}$ of $P$. gingivalis has an optical density of 0.3 at $650 \mathrm{~nm}$.

2.3. Oral Infection. Each experiment included ten agematched female mice, 14 to 16 weeks old at the start of experiments. Mice were given sulfamethoxazole $(0.87 \mathrm{mg} / \mathrm{mL})$ and trimethoprim $(0.17 \mathrm{mg} / \mathrm{mL})$ (Sulfatrim, Goldline Laboratories, Ft. Lauderdale, FL, USA), ad libitum in their drinking water for 10 days, followed by a 3-day antibiotic-free period. Mice were then infected by gavage needle and direct oral exposure three times at 2-day intervals with $10^{9} \mathrm{CFU}$ of live P. gingivalis in $100 \mu \mathrm{L}$ of PBS with $2 \%$ carboxymethylcellulose. Controls received the antibiotic pretreatment and three sham-infections with carboxymethylcellulose without $P$. gingivalis. Forty-two days after the final gavage, mice were euthanized by $\mathrm{CO}_{2}$ [3]. Duplicate experiments yielded the same results; the results from one experiment are shown.
2.4. Measurement of Alveolar Bone Loss. Horizontal bone loss around the maxillary molars of defleshed skulls was assessed under a dissecting microscope $(\times 40)$ fitted with a video image marker measurement system (model VIA 170, Boeckeler Instruments, Inc., Tucson, AZ, USA) standardized to give measurements in fractions of $\mathrm{mm}$. The distance from the cementoenamel junction (CEJ), where the enamel of the tooth crown meets the cementum of the tooth root, to the alveolar bone crest of the jaw (ABC) was measured at a total of 14 buccal sites per mouse (for location of measurement sites see photographs in [11]). Measurements were done in a blinded protocol by one investigator.

As alveolar bone resorbs away, additional root cementum is exposed and the distance from the CEJ to the new location of the $\mathrm{ABC}$ becomes larger. Where the $\mathrm{CEJ}$ to $\mathrm{ABC}$ is larger in infected mice than in sham-infected mice, bone loss has occurred. The $\mathrm{CEJ}$ to $\mathrm{ABC}$ distance is not zero; consequently, the $\mathrm{CEJ}$ to $\mathrm{ABC}$ distance at individual sites in infected mice was subtracted from the mean of the distance at that site in sham-infected mice, giving the $\mathrm{mm}$ of change in bone at that site.

2.5. Reisolation of P. gingivalis from the Oral Cavity. At the time of euthanasia, bacterial samples were collected from the oral cavity using one sterile paper-point per mouse placed along the CEJ for 5 seconds on the buccal surface of the three maxillary molars on the left and 5 seconds along the molars on the right. Each sample was individually plated and incubated as described previously [10].

2.6. P. gingivalis-Specific Antibody. Blood was collected from each mouse at the time of euthanasia. Sera were stored at $-80^{\circ} \mathrm{C}$ for later assessment of specific IgM, IgG, and IgA antibody by enzyme-linked immunosorbent assay (ELISA), as described previously [10], in polystyrene plates (Costar, Corning Inc., Corning, NY, USA) coated with formalinkilled whole $P$. gingivalis ATCC 53977. The ELISA titer was defined as the reciprocal of the highest serum dilution (expressed in $\log _{2}$ ) that produced absorbance readings more than two standard deviations above background levels. The $P$. gingivalis-specific titer of each infected animal was calculated by subtraction of the mean value from the sham-infected animals of that mouse strain.

2.7. Flow Cytometry. Spleens were collected at the time of euthanasia. Fifty $\mu \mathrm{l}$ of mouse spleen cells at a density of $2 \times 10^{7}$ cells $/ \mathrm{ml}$ were washed in $4 \mathrm{ml}$ of wash buffer $(0.2 \mathrm{~g} \mathrm{KCl}$, $8.0 \mathrm{~g} \mathrm{NaCl}, 1.15 \mathrm{~g} \mathrm{Na}_{2} \mathrm{HPO}_{4}, 0.2 \mathrm{~g} \mathrm{KH}_{2} \mathrm{PO}_{4}$ and $0.2 \mathrm{~g} \mathrm{NaN}_{3}$ per liter at $\mathrm{pH}$ 7.2) and pelleted at $110 \times \mathrm{g}$ for 10 minutes at $15^{\circ} \mathrm{C}$. The pellets were resuspended in $1 \mathrm{ml}$ of the same wash buffer and were blocked with $10 \mu \mathrm{l}$ of normal rat IgG (Sigma Chemical Company, St. Louis, MO, USA) and incubated for 15 minutes at $7^{\circ} \mathrm{C}$. Cells were immunostained for 30 minutes at $7^{\circ} \mathrm{C}$ with either $10 \mathrm{ul}$ of prediluted hamster antimouse CD69 conjugated to FITC to show activation status, or phycoerythrin-conjugated hamster antimouse CD19 to mark $\mathrm{B}$ cells or hamster anti-mouse CD4 to mark $\mathrm{CD} 4{ }^{+} \mathrm{T}$ cells, and FITC- or phycoerythrin-labeled hamster IgG as isotype 
controls (The Jackson Laboratory, Bar Harbor, ME, USA). Unadsorbed antibody was removed by adding wash buffer and centrifuging at $60 \times \mathrm{g}$ for 10 minutes at $10^{\circ} \mathrm{C}$. Cells were resuspended in $0.5 \mathrm{ml}$ flow cytometry buffer (the wash buffer with $5 \mathrm{ml} / \mathrm{l}$ fetal bovine serum added). Five $\mu \mathrm{l}$ of propidium iodide at $20 \mu \mathrm{g} / \mathrm{ml}$ were added to determine cell viability. Data were acquired on a FACSORT (Becton-Dickinson, San Jose, CA, USA) and were analyzed using CellQuest. Lymphocytes were gated on the basis of forward scatter and side scatter of incident light [12].

2.8. Statistics. Differences between the infected and sham groups and between infected mice of different strains were evaluated by two-tailed, unpaired $t$-tests (Excel; Microsoft, Redmond, WA, USA).

\section{Results}

The effects of oral infection with P. gingivalis on alveolar bone are shown in Figure 1. In BALB/CJ mice with normal $\operatorname{IgD}$ levels the $\mathrm{CEJ}$ to $\mathrm{ABC}$ distance was larger in infected mice than in sham-infected mice at each of the 14 measurement sites, indicating that the infected $\mathrm{BALB} / \mathrm{cJ}$ mice had lost bone at every site (Figure $1(\mathrm{a})$ ). In contrast, in IgD deficient mice the $\mathrm{CEJ}$ to $\mathrm{ABC}$ distances were the same in infected mice as in sham-infected mice, showing that without $B$ cell $\operatorname{IgD}$ mice did not lose bone at any site (Figure 1(b)).

Summing the amount of bone change at all 14 sites additionally demonstrated that bone loss occurred in immune normal mice but not in IgD deficient mice. The summed change in infected B cell normal BALB/cJ mice was a mean of $-0.302 \pm 0.035 \mathrm{~mm}$ of bone. In contrast, the summed bone change in infected $\mathrm{IgD}$ deficient mice was $0.040 \pm 0.024 \mathrm{~mm}$ $\left(P=1.28 \times 10^{-7}\right)$.

To be sure that lack of bone loss could not be explained by a lack of infection, we reisolated $P$. gingivalis from the oral cavities by paper point. P. gingivalis was present in each of the infected mice of both strains and was not present in any of the uninfected mice (data not shown). The $P$. gingivalis load was actually much higher (a mean of $100 \pm 10$ colonies per plate, $n=10)$ in the IgD deficient mice than in the immune normal mice where the mean was only $2 \pm 1$ colonies per plate (data not shown).

The difference in bacterial load may reflect differences between the mouse strains in their production of $P$. gingivalis-specific serum antibody. After infection, both mouse strains produced a specific antibody response significantly higher $(P<.05)$ than the background levels in sham-infected animals (data not shown); however, the titers of each of the three antibody isotypes in the infected mice were lower in the $\operatorname{IgD}$ deficient mice than in the immune normal mice $(P<.05)$ (Figure 2).

Despite the differences in serum antibody titers, Igh$5^{-/-}$mice are known to have normal proportions of $\mathrm{B}$ cells [8]. This was confirmed in our experiments by flow cytometry measurements on the day of euthanasia, 42 days postinfection by comparing the sham-infected mice of the two strains. The mean percentage of B cells was

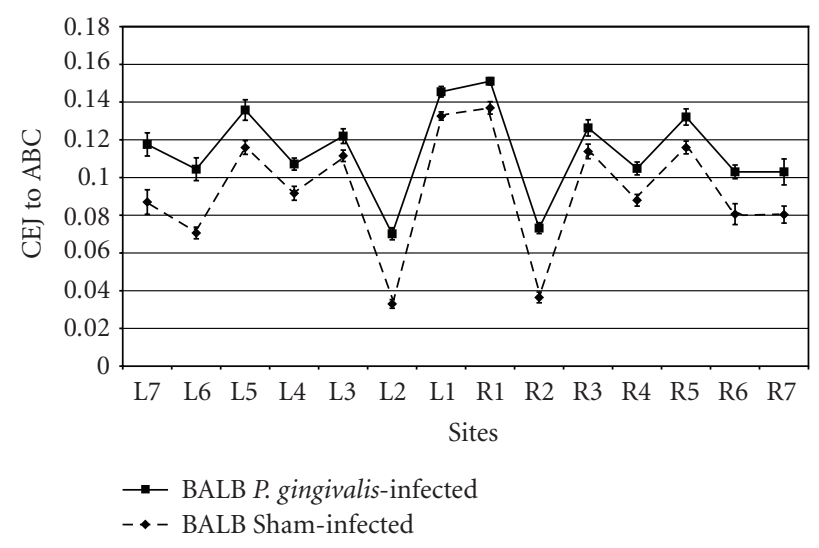

(a)

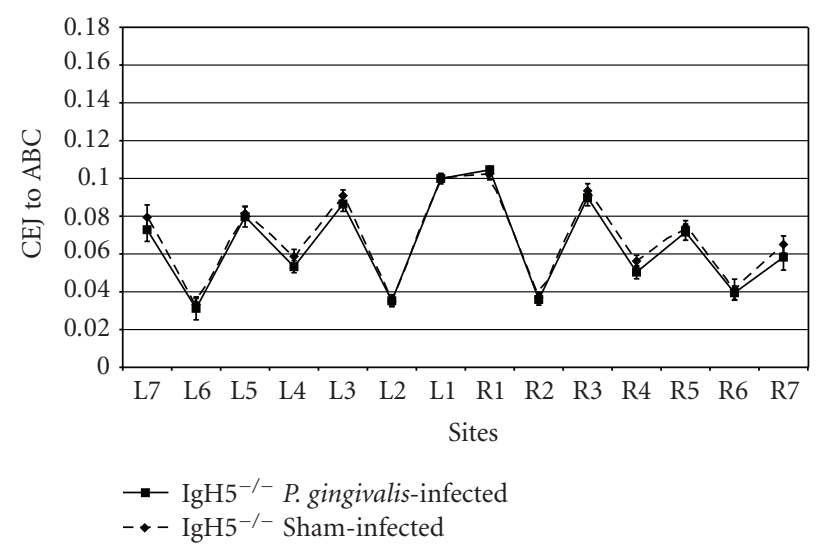

(b)

Figure 1: Changes in bone levels due to oral infection with $P$. gingivalis. The distance from the CEJ on the tooth to the $\mathrm{ABC}$ of the jaw was measured at 14 buccal sites on the maxillary molars, seven sites on the left (L) and seven on the right (R), with site number 1 located closest to the midline. Each point indicates the mean measurement at that site \pm 1 SEM ( $n=10$ mice). (a) Immune normal BALB/cJ mice showed alveolar bone resorption when infected with $P$. gingivalis. The distances from the CEJ to the $\mathrm{ABC}$ were significantly larger in infected mice than in sham-infected mice $(P<.05)$ at each of the 14 sites, indicating that alveolar bone resorbed at every measurement site. (b) IgD deficient $\mathrm{IgH} 5^{-/-}$mice did not show alveolar bone resorption. The distances from the CEJ to the $\mathrm{ABC}$ were the same in $P$. gingivalis-infected mice as in shaminfected mice $(P>.05)$.

higher in $\operatorname{IgD}$ knockout mice than in normal mice, but the difference between the two mouse strains was not statistically significant (Figure 3(a)). In neither mouse strain did $P$. gingivalis-infection change the percentage of total $\mathrm{B}$ cells compared with sham-infected mice (Figure 3(a)). Although total $B$ cell percentages were unchanged, a higher percentage of $B$ cells were activated in infected $B A L B / c J$ mice than in infected IgD knockout mice $(P<.05$; Figure $3(\mathrm{~b}))$.

We also examined the $\mathrm{CD}^{+} \mathrm{T}$ cell populations in the two mouse strains. In $\mathrm{BALB} / \mathrm{cJ}$ mice $P$. gingivalis-infection led to a significant increase in the mean percentage of total viable $\mathrm{CD}^{+} \mathrm{T}$ cells compared with sham-infected $\mathrm{BALB} / \mathrm{cJ}$ mice $(P<.05)$. In IgD deficient mice, however, infection did not 


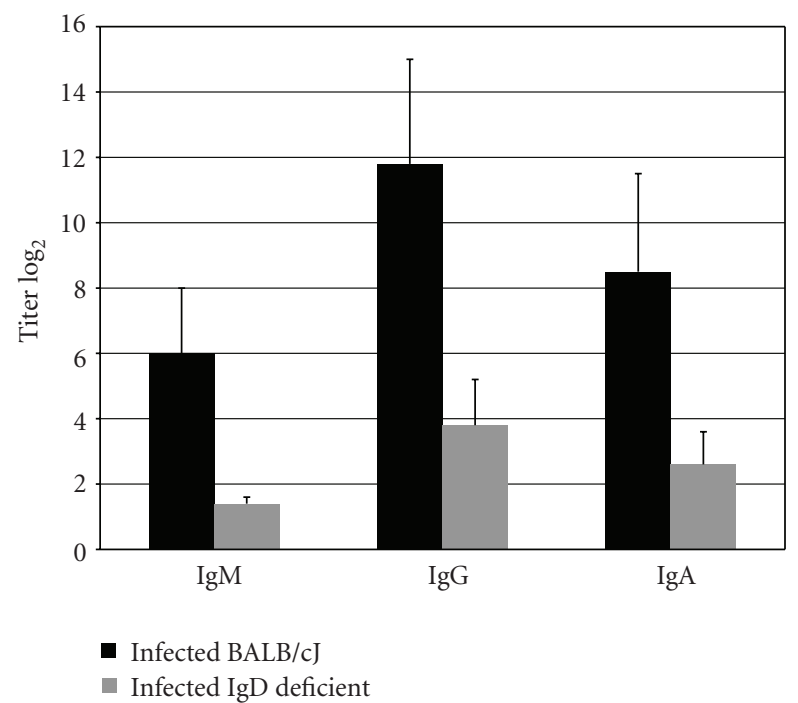

Figure 2: $P$. gingivalis-specific serum antibody titers of all three isotypes were significantly lower in infected $\operatorname{IgD}$ deficient mice compared with immune normal BALB/cJ mice $(P<.05)$. Bars represent the mean anti- $P$. gingivalis titer of infected mice \pm SEM $(n=10)$ after subtraction of the mean value for sham-infected mice of the same strain.

increase the $\mathrm{CD}^{+} \mathrm{T}$ cell population (Figure 4(a)). Similarly, infection activated $\mathrm{CD} 4^{+} \mathrm{T}$ cells in BALB/cJ mice, as shown by the increased percentage of $\mathrm{CD} 69^{+} \mathrm{CD} 4^{+} \mathrm{T}$ cells, but it did not activate $\mathrm{T}$ cells in IgD deficient mice (Figure 4(b)).

\section{Discussion}

In this study, we show that mice with B cells lacking surface IgD do not experience alveolar bone loss after oral infection with $P$. gingivalis (Figure 1). One possible explanation for the lack of bone loss could be that the mice were colonized by with a diminished load of $P$. gingivalis. Reisolation of the bacteria eliminated this possibility; IgD deficient mice actually harbored higher numbers of this bacterium than immune normal mice. Higher colonization may be due to the lower antibody titers found in the IgD deficient (Figure 2). These reduced titers are in line with earlier studies showing that diminished antibody response is due to the delayed affinity maturation characteristic of this IgD mutation [8]. Previous studies in immune normal mice have demonstrated that antibody may decrease bacterial load but antibody is not protective against bone loss: lower antibody titers do not lead to more bone loss [13].

We cannot entirely exclude another possibility; that is, that the resistance to bone loss seen in the IgD deficient mice was due to residual contamination with alleles from the 129 or C57BL/6 progenitor strains. The Igh knockout was originally generated on the C57BL/6 genetic background by gene targeting with an embryonic stem cell line derived from murine strain 129 [8]. BALB/c-Igh- $5^{-/-J}$ mice were produced by backcross onto the BALB/cJ strain for seven generations. Strain $\mathrm{BALB} / \mathrm{cJ}$ is genetically susceptible to bone

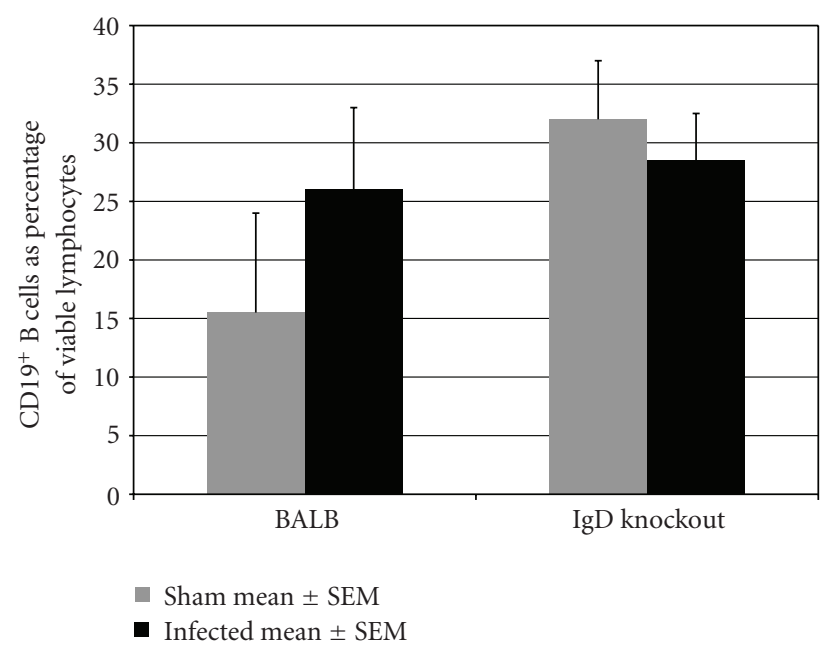

(a)

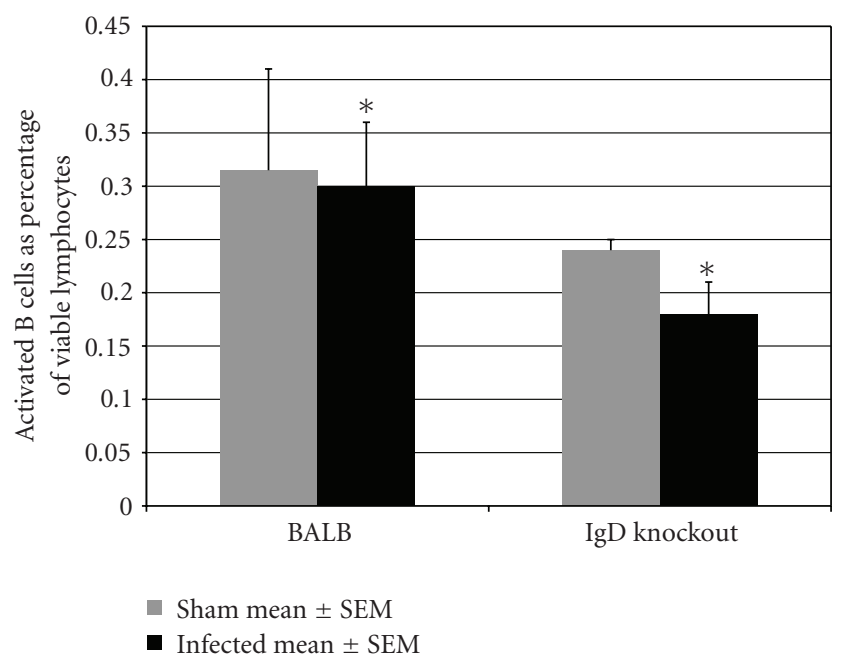

(b)

FIgure 3: $P$ gingivalis-infected IgD deficient mice had a lower proportion of activated $\mathrm{B}$ cells than infected immune normal BALB/CJ mice. (a) The total B cell population: the percentage of total viable $\mathrm{CD} 19^{+} \mathrm{B}$ cells in the sham-infected mice were the same in both strains $(P>.05)$. In neither mouse strain was the total $\mathrm{B}$ cell population changed by $P$. gingivalis infection $(P>.05$, infected compared to sham-infected mice). (b) Activated B cell population: the proportion of activated $\mathrm{B}$ cells in infected $\operatorname{IgD}$ deficient mice were significantly lower than in infected BALB/cJ mice, $(P<.05$, indicated by ${ }^{*}$ ) $n=8 ; 42$ days postinfection.

loss after oral infection with P. gingivalis, while strains 129 and $\mathrm{C} 57 \mathrm{BL} / 6$ show moderate resistance to bone loss in some experiments [11]; however, mice within each cohort do lose bone after infection. In seven backcross generations the progenitor genotypes are predicted to be diluted 1 in $2^{7}$, leaving less than $0.8 \%$ of the progenitor alleles carried into the BALB/cJ genome and then only if they are closely linked to the target Igh gene. In the experiments presented in this paper, no infected $\mathrm{BALB} / \mathrm{C}-\mathrm{Igh}-5^{-/-J}$ mouse showed an increase in the $\mathrm{CEJ}$ to $\mathrm{ABC}$ distance (our measure of bone loss) that was beyond one standard error of the mean value 


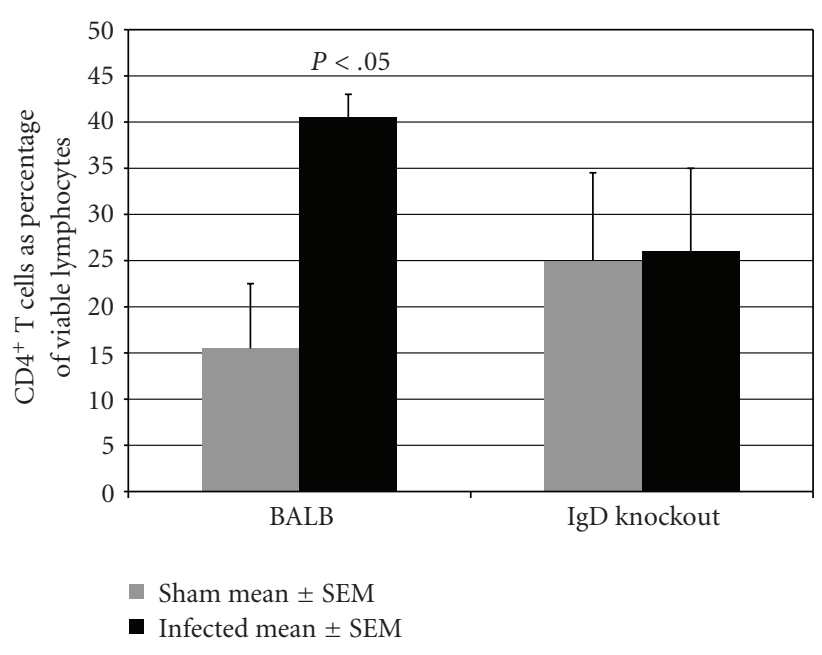

(a)

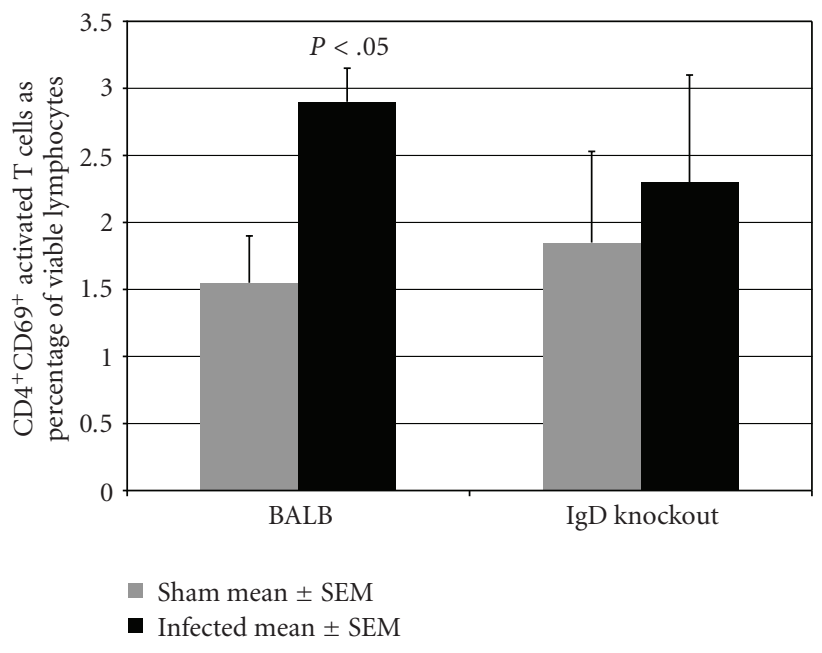

(b)

FIgure 4: $P$. gingivalis-infection increased the proportion of $\mathrm{CD} 4^{+} \mathrm{T}$ cells and activated them in immune normal BALB/cJ mice but not in IgD deficient mice. (a) Total CD4 ${ }^{+} \mathrm{T}$ cell population: in immune normal BALB/cJ mice the percentage of total viable $\mathrm{CD} 4^{+} \mathrm{T}$ cells were higher in infected than in sham-infected $(P<.05)$ but in $\operatorname{IgD}$ deficient mice the percentage was unchanged by infection $(P>.05)$. (b) Activated $\mathrm{CD}^{+}$T cells: In BALB/cJ mice the proportion of activated CD4 ${ }^{+} \mathrm{CD} 9^{+} \mathrm{T}$ cells were higher in $P$. gingivalis-infected than in sham-infected mice $(P<.05)$ but activation was not increased by infection in $\operatorname{IgD}$ deficient mice $(P>.05) . n=10$.

of the shams; that is, the distance from the $\mathrm{CEJ}$ to the $\mathrm{ABC}$ in every infected mouse was within the range of variation of the sham mice. We therefore think it highly unlikely that the absence of bone loss observed in the infected mice is the result of passenger 129 or C57BL/6 gene loci but is instead an intrinsic feature of the Igh deficiency.

We propose that the resistance to bone loss is due to the inability of $\operatorname{IgD}$ deficient $\mathrm{B}$ cells to act as costimulators of antigen-specific $\mathrm{T}$ cells. $\mathrm{T}$ lymphocytes and other cells are normal in Igh- $5^{-/-}$mice [8]. T cells have $\mathrm{IgD}$ receptors that are lectins and bind to $\mathrm{O}$-glycans on $\mathrm{B}$ cell surface $\operatorname{IgD}$ immunoglobulin [14]. These IgD receptors are present on very low numbers of peripheral $\mathrm{T}$ cells but are moved to the surface membrane in response to activation by antigen [9]. The upregulated IgD receptor on an antigen-specific $\mathrm{T}$ cell binds to IgD on a $\mathrm{B}$ cell bearing the same antigen, stabilizing the $\mathrm{T}$ cell receptor/MHC II connection between the two types of lymphocytes, facilitating activation of both.

Other forms of costimulation have been shown to be important in alveolar bone loss. Inflammatory bone resorption triggered by Aggregatibacter (formerly Actinobacillus) actinomycetemcomitans requires activation of Th1 $\mathrm{CD} 4^{+} \mathrm{T}$ cells, and this activation requires costimulation of $\mathrm{B} 7$ on the $\mathrm{T}$ cell surface. Blocking of B7 abrogated costimulation and inhibited bone resorption in a rat model [15]. The present results suggest that $\mathrm{B}$ cell $\mathrm{IgD}$ binding to $\mathrm{CD} 4^{+} \mathrm{T}$ cell $\mathrm{IgD}$ receptors is a pathway to costimulation of both $\mathrm{B}$ cells and $\mathrm{CD}^{+}{ }^{+} \mathrm{T}$ cells in $P$. gingivalis-induced disease. Our experiments show that oral infection of immune normal mice with $P$. gingivalis leads to both serum antibody response (Figure 2, an indication of $\mathrm{B}$ cell activation) and to higher numbers and activation of $\mathrm{CD} 4^{+} \mathrm{T}$ cells (Figure 4$)$. In contrast, Igh-5 $5^{-/-}$ mice lacking $\mathrm{IgD}$ showed signs of less activation of both $\mathrm{B}$ and $\mathrm{T}$ cells. They produced lower antibody titers (Figure 2), had fewer activated B cells (Figure 3), and did not show an increase in $T$ cell population or activation at 42 days after infection (Figure 4).

The mechanism by which this cognate $\mathrm{B}$ and $\mathrm{T}$ cell activation stimulates bone loss is not known at this time. It is not likely to be due to the effect of $\mathrm{IgD}$ deletion on antibody secretion, as antibody is not protective against bone loss [13]. One well-studied immunological pathway to bone loss is upregulation of RANK-L on activated lymphocytes. Both $\mathrm{B}$ cells and $\mathrm{T}$ cells express membrane bound and soluble RANK-L after activation [16, 17], and bone loss can be triggered by the binding of this ligand to RANK on preosteoclasts. However, both $\mathrm{CD}^{+}$and $\mathrm{CD} 8^{+} \mathrm{T}$ cells can express RANK-L after activation [16]. We have shown that $\mathrm{CD}^{+} \mathrm{T}$ cells and their cytokines are involved in alveolar bone loss in mice, but that $\mathrm{CD} 8^{+} \mathrm{T}$ cells are not [3]. Others have also implicated $\mathrm{CD} 4^{+}$cells $[2,15,18]$, suggesting that there may a pathway in addition to RANK-L that is particular to $\mathrm{CD}^{+}$but not $\mathrm{CD} 8^{+} \mathrm{T}$ cells. Although we have some preliminary data showing that the proportion of $\mathrm{CD} 4^{+}$ spleen cells expressing membrane surface RANK-L was the same in infected immune normal mice that lost bone as it was in IgD deficient mice that did not lose bone (data not shown), we have not examined RANK-L expression on $\mathrm{T}$ or $\mathrm{B}$ cells in the gingiva.

One pathway that could distinguish between $\mathrm{CD} 4^{+}$and $\mathrm{CD}^{+} \mathrm{T}$ cells is the pathway suggested by these experiments, that is, activation through the $\mathrm{T}$ cell $\mathrm{IgD}$ receptor. In mice, only $\mathrm{CD}^{+} \mathrm{T}$ cells express $\mathrm{IgD}$ receptors and so $\mathrm{CD} 8^{+} \mathrm{T}$ cells cannot participate in the costimulation [9]. $\mathrm{CD}^{+} \mathrm{T}$ cell/ B cell interaction may provide sufficient amplification of RANK-L upregulation that the cells triggering osteoclasts are largely restricted to B cells and $\mathrm{CD} 4^{+} \mathrm{T}$ cells. Han et al. have shown that adoptive transfer of antigen-responsive $\mathrm{B}$ cells 
can induce bone loss in rats that are congenitally athymic and therefore $T$ cell deficient [19]. It is possible that $B$ cells are alone responsible for the effects on bone loss seen in these experiments, but the activation of $\mathrm{CD}^{+} \mathrm{T}$ cells over an extended period of time (42 days postinfection; Figure 4) would argue that $\mathrm{T}$ cell activation is playing at least an amplifying role, either through RANK-L or through increased secretion of bone resorptive cytokines $[3,20]$.

\section{Conclusion}

Genetic deletion of IgD was shown here to diminish T and B cell activation and to inhibit alveolar bone loss in mice. This study suggests a new pathway through which oral infection with $P$. gingivalis can result in loss of alveolar bone. In response to oral infection, $\operatorname{IgD}$ on the surface of $\mathrm{B}$ cells binds to $\mathrm{IgD}$ receptors on $\mathrm{CD} 4^{+} \mathrm{T}$ cells, resulting in coactivation of both B and T cells of the immune system. Such B and T cell activation can, in turn, activate osteoclasts and trigger bone loss. Chronic periodontitis is a widespread infectious disease; therefore, elucidation of the mechanisms through which the immune responses to infection trigger damage rather than protection is of clinical importance.

\section{Acknowledgment}

This research is supported by the U.S. Public Health Service Grants R01 DE10728 to PJB and R01 DK56597 to DCR and by a Grant from the Howard Hughes Medical Institute to Bates College.

\section{References}

[1] M. A. Taubman, P. Valverde, X. Han, and T. Kawai, "Immune response: the key to bone resorption in periodontal disease," Journal of Periodontology, vol. 76, no. 11, supplement, pp. 2033-2041, 2005.

[2] M. A. Taubman, T. Kawai, and X. Han, "The new concept of periodontal disease pathogenesis requires new and novel therapeutic strategies," Journal of Clinical Periodontology, vol. 34, pp. 370-376, 2007.

[3] P. J. Baker, M. Dixon, R. T. Evans, L. Dufour, E. Johnson, and D. C. Roopenian, "CD4 ${ }^{+} \mathrm{T}$ cells and the proinflammatory cytokines gamma interferon and interleukin- 6 contribute to alveolar bone loss in mice," Infection and Immunity, vol. 67, no. 6, pp. 2804-2809, 1999.

[4] P. J. Baker, J. Garneau, L. Howe, and D. C. Roopenian, “Tcell contributions to alveolar bone loss in response to oral infection with Porphyromonas gingivalis," Acta Odontologica Scandinavica, vol. 59, no. 4, pp. 222-225, 2001.

[5] M. A. Taubman and T. Kawai, "Involvement of T-lymphocytes in periodontal disease and in direct and indirect induction of bone resorption," Critical Reviews in Oral Biology and Medicine, vol. 12, no. 2, pp. 125-135, 2001.

[6] Y.-T. A. Teng, "Mixed periodontal Th1-Th2 cytokine profile in Actinobacillus actinomycetemcomitans-specific osteoprotegerin ligand (or RANK-L)-mediated alveolar bone destruction in vivo," Infection and Immunity, vol. 70, no. 9, pp. 5269-5273, 2002 .
[7] Y. Harada, X. Han, K. Yamashita, et al., "Effect of adoptive transfer of antigen-specific B cells on periodontal bone resorption," Journal of Periodontal Research, vol. 41, no. 2, pp. 101-107, 2006.

[8] J. Roes and K. Rajewsky, "Immunoglobulin D (IgD)-deficient mice reveal an auxiliary receptor function for IgD in antigenmediated recruitment of B cells," Journal of Experimental Medicine, vol. 177, no. 1, pp. 45-55, 1993.

[9] S. M. L. Tamma, Y. Wu, I. Toporovsky, V. Lima, and R. F. Coico, "IgD receptor-mediated signal transduction in T cells," Cellular Immunology, vol. 207, no. 2, pp. 110-117, 2001.

[10] P. J. Baker, R. T. Evans, and D. C. Roopenian, "Oral infection with Porphyromonas gingivalis and induced alveolar bone loss in immunocompetent and severe combined immunodeficient mice," Archives of Oral Biology, vol. 39, no. 12, pp. 1035-1040, 1994.

[11] P. J. Baker, M. Dixon, and D. C. Roopenian, "Genetic control of susceptibility to Porphyromonas gingivalis-induced alveolar bone loss in mice," Infection and Immunity, vol. 68, no. 10, pp. 5864-5868, 2000.

[12] P. J. Baker, L. Howe, J. Garneau, and D. C. Roopenian, “T cell knockout mice have diminished alveolar bone loss after oral infection with Porphyromonas gingivalis," FEMS Immunology and Medical Microbiology, vol. 34, no. 1, pp. 45-50, 2002.

[13] P. J. Baker, S. Carter, M. Dixon, R. T. Evans, and D. C. Roopenian, "Serum antibody response to oral infection precedes but does not prevent Porphyromonas gingivalis-induced alveolar bone loss in mice," Oral Microbiology and Immunology, vol. 14, no. 3, pp. 194-196, 1999.

[14] C. D. Swenson, T. Patel, R. B. Parekh, et al., "Human T cell IgD receptors react with O-glycans on both human IgD and IgA1," European Journal of Immunology, vol. 28, no. 8, pp. 2366-2372, 1998.

[15] T. Kawai, R. Eisen-Lev, M. Seki, J. W. Eastcott, M. E. Wilson, and M. A. Taubman, "Requirement of B7 costimulation for Th1-mediated inflammatory bone resorption in experimental periodontal disease," Journal of Immunology, vol. 164, no. 4, pp. 2102-2109, 2000.

[16] D. H. Jones, Y.-Y. Kong, and J. M. Penninger, "Role of RANKL and RANK in bone loss and arthritis," Annals of the Rheumatic Diseases, vol. 61, supplement 2, pp. ii32-ii39, 2002.

[17] T. Kawai, T. Matsuyama, Y. Hosokawa, et al., "B and T lymphocytes are the primary sources of RANKL in the bone resorptive lesion of periodontal disease," The American Journal of Pathology, vol. 169, no. 3, pp. 987-998, 2006.

[18] Y.-T. A. Teng, "The role of acquired immunity and periodontal disease progression," Critical Reviews in Oral Biology and Medicine, vol. 14, no. 4, pp. 237-252, 2003.

[19] X. Han, T. Kawai, J. W. Eastcott, and M. A. Taubman, "Bacterial-responsive B lymphocytes induce periodontal bone resorption," The Journal of Immunology, vol. 176, no. 1, pp. 625-631, 2006.

[20] P. J. Baker, "The role of immune responses in bone loss during periodontal disease," Microbes and Infection, vol. 2, no. 10, pp. 1181-1192, 2000. 


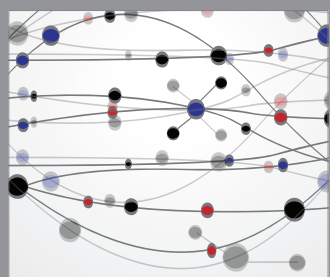

The Scientific World Journal
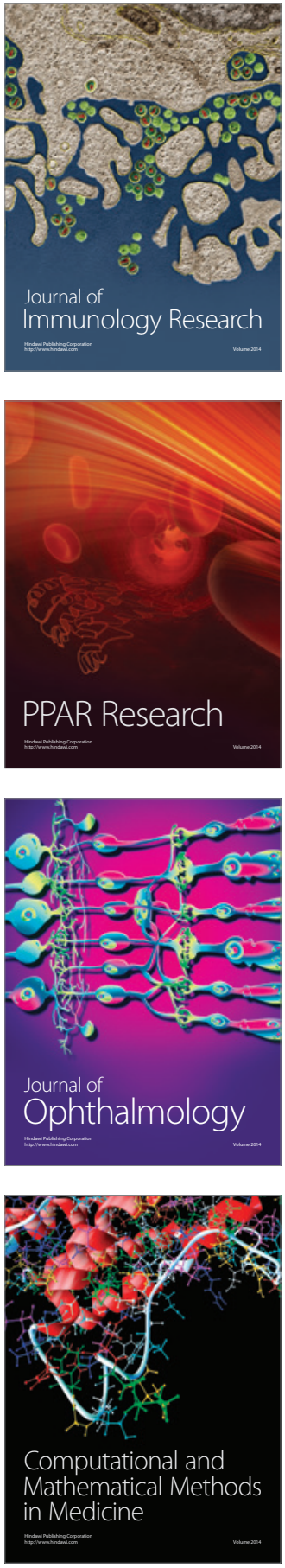

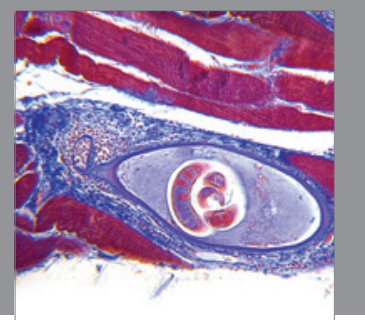

Gastroenterology

Research and Practice
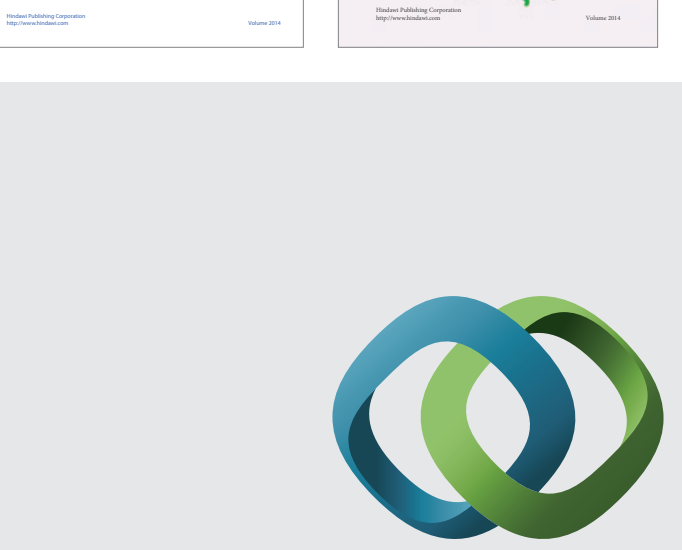

\section{Hindawi}

Submit your manuscripts at

http://www.hindawi.com
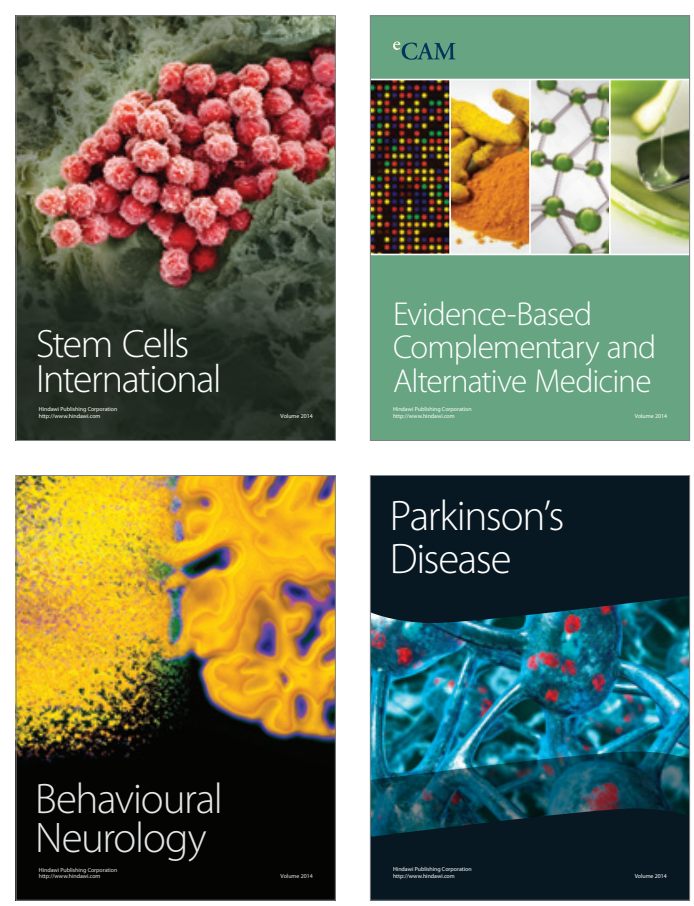

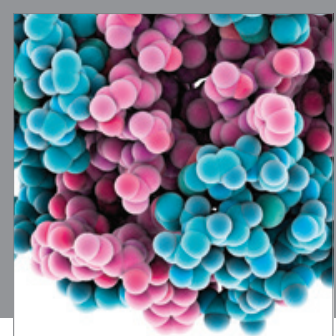

Journal of
Diabetes Research

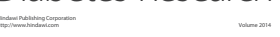

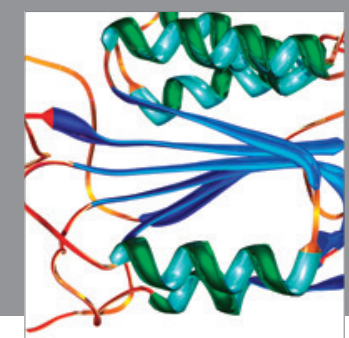

Disease Markers
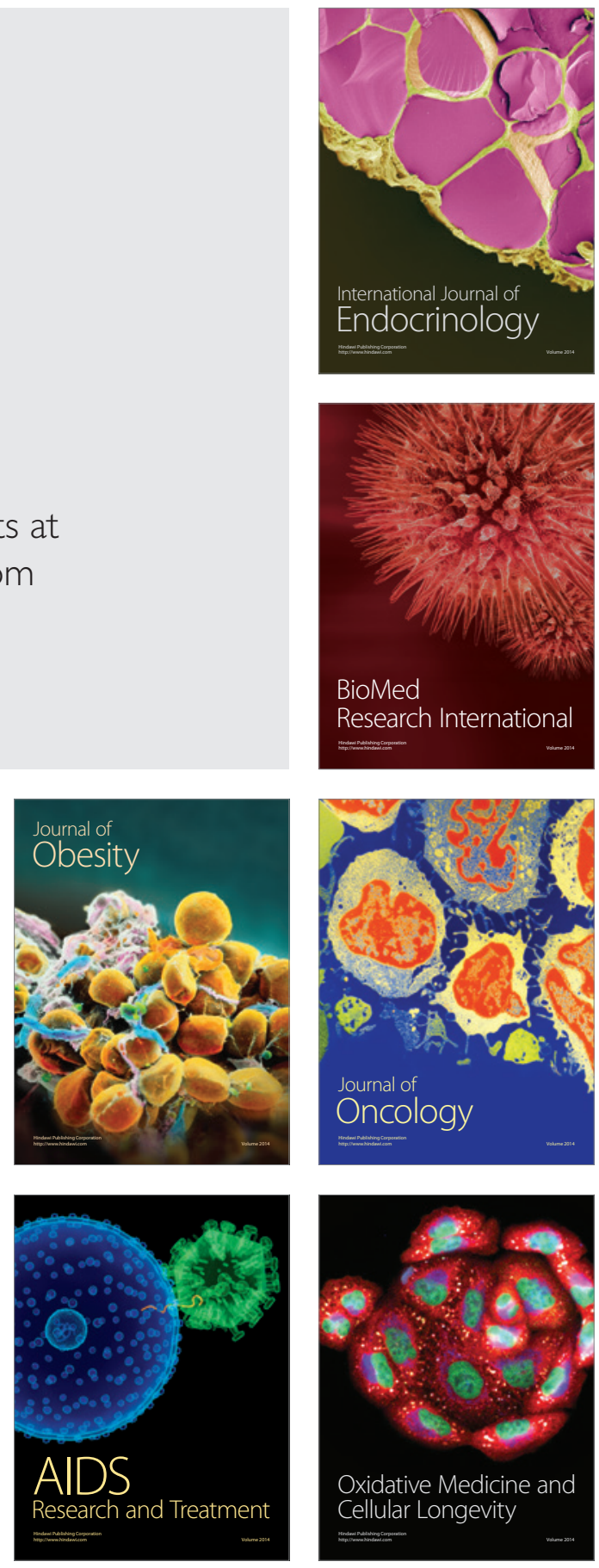